\title{
Correction to: Determination of emergency roads to emergency accommodation using loss analysis results
}

Sajad Ganjehi ${ }^{1}$ and Khadijeh Norouzi Khatiri ${ }^{*}$ (i)

\section{Correction to: Geoenvironmental Disasters (2021) 8:15 https://doi.org/10.1186/s40677-021-00190-2}

Following publication of the original article (Ganjehi and Khatiri 2021), the authors identified an error in the Abstract. In addition there was a technical error which caused language errors throughout the article and the digits above the scale bar in Figures 1, 9, 10, 11, 12, 15, 17 did not show appropriately.

The language errors are corrected, the word that was added due to the technical error: 'TEMP' was removed in all occasions and the digits above the scale bar in the Figures are corrected in the original article (Ganjehi and Khatiri 2021).

The correct Abstract is given hereafter.

\begin{abstract}
This study presents a method to identify safe places to build temporary accommodation and accessible relief routes using the results of damage analysis for an earthquake within the bounds of probability for the city of Shiraz in Iran. The commonly used HAZUS damage estimation method was used. The most influential factors on the location of safe temporary accommodation in Shiraz were determined by use of the damage results, the Analytic Hierarchy Process (AHP) model, and Expert Choice
\end{abstract}

software. A map for the resulting optimal locations of temporary accommodation was prepared. Subsequently, all of the parameters influencing the safety of emergency evacuation efforts and the relief network were identified and the impact rate of each one was determined based on expert opinions through AHP. Based on the resultant importance of each index, roads were weighted and coded. The optimally safe routes for relief and emergency evacuation were determined. The results suggested that different indices suggest different relief routes and the optimal route was obtained through overlapping the data layers according to the importance of each parameter. This optimal route could provide maximum services in the minimum time and subsequently create capacity building in urban crisis management.

Keywords: Earthquake, Emergency accommodation, Damage, Emergency evacuation, AHP

All the changes that were requested are specified in this correction and the original article (Ganjehi and Khatiri 2021) has been corrected. original author(s) and the source, provide a link to the Creative Commons licence, and indicate if changes were made. The images or other third party material in this article are included in the article's Creative Commons licence, unless indicated otherwise in a credit line to the material. If material is not included in the article's Creative Commons licence and your intended use is not permitted by statutory regulation or exceeds the permitted use, you will need to obtain permission directly from the copyright holder. To view a copy of this licence, visit http://creativecommons.org/licenses/by/4.0/. 


\section{Author details}

'Disaster Management, School of Environment, College of Engineering, University of Tehran, Tehran, Iran. ${ }^{2}$ Water Resources, School of Environment, College of Engineering, University of Tehran, Tehran, Iran.

Published online: 01 September 2021

\section{Reference}

Ganjehi S, Khatiri KN (2021) Determination of emergency roads to emergency accommodation using loss analysis results. Geoenviron Disasters 8:15. https://doi.org/10.1186/s40677-021-00190-2

\section{Publisher's Note}

Springer Nature remains neutral with regard to jurisdictional claims in published maps and institutional affiliations.

\section{Submit your manuscript to a SpringerOpen ${ }^{\odot}$ journal and benefit from:}

- Convenient online submission

- Rigorous peer review

- Open access: articles freely available online

- High visibility within the field

- Retaining the copyright to your article

Submit your next manuscript at $\boldsymbol{\nabla}$ springeropen.com 